\title{
Relationship between Poverty, Women Empowerment and SHGs: A Study of Indian States
}

\author{
Dr. Ravindra K \\ Lecturer, Gulf College, Sultanate of Oman \\ ravikonaje@rediffmail.com
}

Dr. Abhay Kumar Tiwari

Faculty Member, IBS Business School Dehradun

\begin{abstract}
Self Help Group (SHG) model of micro credit in India has been considered as a new panacea for women empowerment and reduction of poverty. Thanks to the initiative taken by Reserve Bank of India, NABARD and the effort of several Non-Governmental Organizations (NGOs) as well as the Governments of various states, over the years there is a tremendous increase in the number of SHGs in India. But the number varies from region to region and state to state. This variation is also true for the states in the achievement of poverty alleviation and women empowerment. In this study authors attempted to analyse the relationship between poverty, women empowerment and SHGs based on the ranking of some major states in terms of the number of poor people, level of women empowerment and the number of SHGs with the help of NABARD and NFHS-3 data. The outcome of this study shows that there is a relationship between poverty, women empowerment and SHGs.
\end{abstract}

\section{INTRODUCTION}

Poverty eradication and improving the status of women who constitute almost 50 per cent of the total population of the country remained a major challenge for the Government and the policy makers in India. About 26 per cent still live in a status of acute poverty. Even though the number changes from state to state, poverty in India is considered to be a mass problem especially in rural area. Empowerment of women and eradication of poverty is very critical for the development of the country since it will enhance both the quality and the quantity of human resources available for development. Failing in these efforts will deprive both men and women in getting the fruits of development. Even though various programmes are announced in different Five Year Plans and legislations are passed to raise the status of women, it failed in achieving the perceived goal, due to either bureaucratic hurdle or inefficiency of implementing agencies. Poverty in India is predominantly rural in character and is more pronounced among vulnerable groups like SC's, ST's and women belong to landless and small farming classes, and dependent on wage employment. Therefore, reaching the poor requires working with them to learn about their needs, understanding how development decisions are made in their communities and identifying institutions and mechanisms that can get opportunities and recourses into their own hands. This can happen through investments in human capital such as local level institutions and participatory process and support for community based development efforts planned and implemented from bottom up (Srinivasan;1996).

Micro-credit has been advocated as the new panacea for women empowerment and reduction of poverty. SHG movement has made tremendous strides in India over the years and it has become popular in view of the multi-pronged benefits reaped/ receivable from micro finance services by the poor. Self Help Groups (SHGs) have become the common vehicle of development process, converging all development programmes. These groups have acquired a prominent status in maximizing social and financial returns through providing considerable social and income opportunity to the members. The promotion of entrepreneurship for the poor rural women is a powerful medium to resolve several socio-economic problems. The Radhakrishnan committee on credit related issues under Swarnajayanthi Gram Swarozgar Yojana (SGSY) has observed the potentials of such groups in implementing various poverty alleviation programmes in rural areas and reported that such institutions are in embryonic form in women's SHGs especially in some southern states. Kudumbasree in Kerala, and Society for Elimination of Rural Poverty in Andhra Pradesh for example, 
initially set up with Government support as collective entities to receive small loans are now involved in a range of different activities. In Tamil Nadu the Weavers Development Corporation is playing similar role. If these SHGs are used for distributing PDS grain, BPL cards or NREGA job cards, a sharp improvement in the effectiveness of a whole range of anti poverty programmes would be realised. (Mundle 2010)

\section{SHGs as an Agent of Socio-Economic Change}

SHGs are formed with an implicit objective to combat unjust social relationship by increasing people's participation through their empowerment. The emphasis is also on human resource development. The small size of SHGs not only ensures active participation, but also promotes group dynamics in decision-making and greater transparency. Though the primary objective of microfinance interventions is to help the poor to surmount poverty, they also assist them to undertake financially viable enterprises. Puhazendi and Satyasai (2001) evaluated the performance of SHGs with special reference to social and economic empowerment. The findings of their study of SHGs in 11 states revealed that SHGs as institutional arrangement could positively contribute to the economic and social empowerment of rural poor. Manimekalai and Rajeshwari (2001) highlighted that provision of micro-finance by the Non Government Organisations (NGOs) to women SHGs has helped the groups to achieve a measure of economic and social empowerment. It has developed a sense of leadership, organizational skill, management of various activities of a business, right from acquiring finance, identifying raw material, market and suitable diversification and modernization.

SHGs create awareness among the members about various social evils. The women SHGs have also emerged as a social pressure groups for bringing about social change and transformation. The studies pertaining to micro finance and women empowerment simply demonstrates that there has been significant contribution of self help group based micro finance in the social change and empowerment of the poor. Moreover, micro finance activities promoted by either NGOs or government agencies have no doubt created opportunities for promotion of income generating activities and enhance income to the poor. Puhazhendhi (1999) analyzed the functioning of SHG's, in performance, sustainability, empowerment of women, economic impact on the members, future potentials etc. $\mathrm{He}$ concluded that SHG's in Tamil Nadu are performing well towards social change and transformation. The emerging trends are leading to positive direction of empowerment of members and promotion of micro finance. The adoption by the central government of the SHG concept as its primary antipoverty self-employment program (SGSY) also aided program growth. Andhra Pradesh state made SHGs their flagship strategy in rural development resulting in various government agencies forming SHGs.

\section{GROWTH AND Distribution OF SHGS}

The SHG movement has come of age after nearly two decades of experimentation. The SHGs today considered as a model of inclusive growth and become a vehicle to pursue diverse developmental goals. A rapid growth has been observed in the SHG Bank Linkage programme during the last decade and particularly in the last few years. As on 31 March 2009, total 61,21,147 SHGs were having saving bank accounts with the banking sector with outstanding savings of Rs. 5,545.62 crore as against 50,09,794 SHGs having savings of Rs. 3785.39 crore as on 31 March 2008, thereby having growth rate of $22.2 \%$ and $46.5 \%$ respectively. Thus, more than 8.6 crore poor households were associated with banking agencies under SHG-Bank Linkage Programme. Out of the total saving linked and credit linked SHGs, exclusive women SHGs saving linked and credit linked with banks were $79.5 \%$ and $85.4 \%$, respectively. Further, the percentage of loans outstanding of exclusive women SHGs to total SHGs which was $78.45 \%$ as on 31 March 2008 had increased to $81.93 \%$ as on 31. March 2009. (NABARD 2009).However, there are major regional variations in the number of SHG and bank linkage. A large number of SHGs are concentrated in the southern region of India. For instance, Andhra Pradesh, Karnataka and Tamil Nadu accounts for nearly $46 \%$ of the cumulative number of SHGs bank linked in India. As the number of SHGs is increasing they are concentrating in some states while in other states its spread is slow. In order to increase the numbers of SHGs in their record most of the Self Help Group Promotion Institutes (SHGPIs) are only able to explore the selective regions (Sa-Dhan 2003).Instead of Poverty and backwardness being the criteria for forming SHGs the promoters prioritized creditworthiness and the environment where it is easy to convince people. This resulted not only in deteriorating quality of SHGs but also denied the benefit of the movement by excluding a large chunk of deserved people in the remote and underdeveloped regions. SHGs will 
become a model of inclusive growth only when it is able to reach the remotest area of the country and cover the majority of people, especially women living below poverty line.

\section{TARget Oriented V/S NeEd Oriented ApProACH}

The target- oriented approach both for formation of SHGs and credit linkage has been a matter of concern which had its own negative implications on the quality and outreach. When SHG spread is analysed with reference to poverty, backwardness and level of women empowerment the glaring differences between regions highlights the need for the outreach of SHG movement in those regions. Many potential pockets in north east and east are deprived of sizeable chunk of SHGs (Devaprakash 2005).

Various research works analyse the growth, spread and importance of SHGs. Some works even attempted to address the problem of lopsided growth and need to maintain the balance in the spread of SHGs (Pankajand Golait 2009).Meanwhile researches also point out the deteriorating quality of SHGs due to its uncontrolled growth (Sa-Dhan 2003, Devaprakash 2005). In the present study authors made an attempt to identify the relationship between poverty, women empowerment and SHGs in different states by analysing the prevailing socio-economic conditions. By ranking states in accordance with poverty, women empowerment and SHGs a relationship between these three aspects has been analysed. National Bank for Agriculture and Rural Development (NABARD) and National Family and Health Survey -3 (NFHS-3) data are used for this analysis. The study, observes that in most of the major states of India there is a relationship between poverty, women empowerment and SHGs.

\section{RESULT AND DISCUSSION}

The major objective of this study is to establish the relationship between poverty, women empowerment and SHGs. The ranking of states in terms of poverty, women empowerment and SHGs shows that in the major states of India, which has high number of SHGs pioneer in terms of poverty and women empowerment. Those states recorded less number of SHGS found lagging behind in terms of poverty and women empowerment.

\section{Poverty AND SHGs}

Table 1 shows state wise distribution of SHGs bank linked and the number of rural people living below poverty line (BPL) and the SC/ST population along with the percentage. The table shows that in states like Bihar (32.90), Chattisgarh 31.20), Jharkhand (40.20), Madhya Pradesh (29.80), Orissa (39.80), Uttar Pradesh (25.30) and Uttarakhand (31.70) the percentage of BPL rural population is higher than all India percentage of 21.80. The percentage distribution of SC/ST population living in these states is 5.51, 3.61, 4.10, 8.54, 5.68, 14.08 and 0.71 respectively. In Rajasthan it is 6.71 . Incidentally, out of the total SHGs in India, in Bihar its percentage is 2.12, whereas in other states like Chattisgarh (1.85), Jharkhand (0.81), Madhya Pradesh (2.84), Rajasthan 3.15, and in Uttar Pradesh it is 6.41. It is quite low in comparison with some states where it is considered to be the concentration of SHGs are taken place, such as Andhra Pradesh (20.93), Karnataka (7.48), Kerala (5.87), Maharashtra (11.20), and Tamil Nadu (11.93). This number is comfortably sufficient if we consider the Number of people living below poverty line and the percentage of SC/ST people. In India poverty is a common phenomenon among the rural population. Any programme initiated by the government to uplift these people from below poverty line is either not implemented properly or failed to achieve its goal. An honest and collective effort from the government and NGO is required make sure the participation of such people in the development activities. SHGs being a source of credit, entrepreneurial development, women empowerment and as an implementing agency of various government programmes go a long way in lessening the incidence of poverty in these regions.

Table1. State wise Number and Percentage of SHGs bank linked, Rural Poverty and SC/ST population

\begin{tabular}{|c|c|c|c|c|c|}
\hline State & $\begin{array}{c}\text { No. of } \\
\text { SHGs }\end{array}$ & $\begin{array}{c}\text { Rural BPL Population in lakh ** } \\
(\%)\end{array}$ & $\begin{array}{c}\text { SC/ST } \\
\text { population*** }\end{array}$ & $\begin{array}{c}\text { \% of } \\
\text { SC/ST }\end{array}$ & $\begin{array}{c}\text { \% share } \\
\text { of SHGs }\end{array}$ \\
\hline Andhra Pradesh & 1280900 & $\begin{array}{c}43.21 \\
(7.50)\end{array}$ & 17363600 & 6.93 & 20.93 \\
\hline Arunachal Pradesh & 5148 & $\begin{array}{c}1.47 \\
(17.00)\end{array}$ & 711346 & 0.28 & 0.08 \\
\hline Assam & 180996 & $\begin{array}{c}41.46 \\
(17.00)\end{array}$ & 5134519 & 2.05 & 2.96 \\
\hline Bihar & 130005 & $\begin{array}{c}262.92 \\
(32.90)\end{array}$ & 13806959 & 5.51 & 2.12 \\
\hline
\end{tabular}


Dr. Ravindra K \& Dr. Abhay Kumar Tiwari

\begin{tabular}{|c|c|c|c|c|c|}
\hline Chhattisgarh & 112982 & $\begin{array}{l}54.72 \\
(31.20)\end{array}$ & 9035318 & 3.61 & 1.85 \\
\hline Goa & 5892 & $\begin{array}{l}0.13 \\
(1.90)\end{array}$ & 24357 & 0.01 & 0.10 \\
\hline Gujarat & 105046 & $\begin{array}{l}46.25 \\
(13.90)\end{array}$ & 11073875 & 4.42 & 1.72 \\
\hline Haryana & 33257 & $\begin{array}{c}14.57 \\
(9.20)\end{array}$ & 4091110 & 1.63 & 0.54 \\
\hline Himachal Pradesh & 41744 & $\begin{array}{l}4.10 \\
(7.20)\end{array}$ & 1746757 & 0.70 & 0.68 \\
\hline Jammu \& Kashmir & 2349 & $\begin{array}{l}2.20 \\
(2.70)\end{array}$ & 1876134 & 0.75 & 0.04 \\
\hline Jharkhand & 49753 & $\begin{array}{l}89.76 \\
(40.20)\end{array}$ & 10276388 & 4.10 & 0.81 \\
\hline Karnataka & 457389 & $\begin{array}{l}43.33 \\
(12.00)\end{array}$ & 12027916 & 4.80 & 7.48 \\
\hline Kerala & 358863 & $\begin{array}{c}23.59 \\
(9.60)\end{array}$ & 3488130 & 1.39 & 5.87 \\
\hline Madhya Pradesh & 173725 & $\begin{array}{c}141.99 \\
(29.80)\end{array}$ & 21388651 & 8.54 & 2.84 \\
\hline Maharashtra & 685324 & $\begin{array}{c}128.43 \\
(22.20)\end{array}$ & 18458932 & 7.37 & 11.20 \\
\hline Manipur & 9474 & $\begin{array}{l}2.86 \\
(17.00)\end{array}$ & 801178 & 0.32 & 0.15 \\
\hline Meghalaya & 9625 & $\begin{array}{l}3.32 \\
(17.00)\end{array}$ & 2004001 & 0.80 & 0.16 \\
\hline Mizoram & 4230 & $\begin{array}{l}0.78 \\
(17.00)\end{array}$ & 839582 & 0.34 & 0.07 \\
\hline Nagaland & 6057 & $\begin{array}{l}2.94 \\
(17.00)\end{array}$ & 1774026 & 0.71 & 0.10 \\
\hline Orissa & 441960 & $\begin{array}{c}129.29 \\
(39.80)\end{array}$ & 14227144 & 5.68 & 7.22 \\
\hline Punjab & 39155 & $\begin{array}{l}9.78 \\
(5.90)\end{array}$ & 7028723 & 2.81 & 0.64 \\
\hline Rajasthan & 192479 & $\begin{array}{l}66.69 \\
(14.30)\end{array}$ & 16792168 & 6.71 & 3.15 \\
\hline Sikkim & 1752 & $\begin{array}{l}0.85 \\
(17.00)\end{array}$ & 138570 & 0.06 & 0.03 \\
\hline Tamil Nadu & 730092 & $\begin{array}{l}56.51 \\
(16.90)\end{array}$ & 12508825 & 5.00 & 11.93 \\
\hline Tripura & 22811 & $\begin{array}{l}4.70 \\
(17.00)\end{array}$ & 1549150 & 0.62 & 0.37 \\
\hline Uttar Pradesh & 391906 & $\underset{(25.30)}{357.68}$ & 35256340 & 14.08 & 6.41 \\
\hline UttaraKhand & 34302 & $\begin{array}{l}21.11 \\
(31.70)\end{array}$ & 1773315 & 0.71 & 0.56 \\
\hline West Bengal & 609439 & $\begin{array}{c}146.59 \\
(24.20)\end{array}$ & 22859349 & 9.13 & 9.96 \\
\hline Delhi & 2014 & $\begin{array}{l}0.01 \\
(0.10)\end{array}$ & 2343255 & 0.94 & 0.03 \\
\hline All India & 6121147 & $\begin{array}{c}1702.99 \\
(21.80)\end{array}$ & 250399618 & 100.00 & 100.00 \\
\hline
\end{tabular}

Note: *No. of SHGs as on 31 March 2009

Source: NABARD - Progress under Microfinance - as on 31 March 2009.

** Percentage of rural people below poverty line 2004-05 (Based on MRP Consumption)

Source: $R B I$

***Source: Census of India 2001.

$\%$ of SC/ST = Total State population/Total SC-ST Population $* 100$

$\%$ of SHG = Total No. of SHGs in India/No. of SHGs in the State * 100 


\section{WOMEN EMPOWERMENT AND SHG}

Role of SHGs appreciated much for its outstanding contribution to the women empowerment. Being a small group of likeminded women formed for a common goal set by the promoters of the groups, SHGs undergo its unique procedures to materialize these goals. In the process of conducting routines of the group the members are exposed to activities such as leading the team, keeping accounts, discussion of common issues, entrepreneurship development, etc. These activities gradually increase the level of self esteem of members. It improves capability of the members in decision making, become more sensitive towards social, political and economic problems in and around them. The lessons learnt in these groups will reflect overall change in the understanding and reaction towards the existing customs and traditions which kept them away from the mainstream society. Empowered women will also participate in various decision making activities along with her male partner regarding household and family matters.

Change in women's contribution to society is one of the striking phenomena of the late twentieth century (Narasaiah, 2004).Giving women the opportunity to realise their potential in all spheres of societymicro-credit plays an important role in empowering women. Similarly, Cheston \& Kuhn (2004) in their study concluded that micro-finance programmes have been very successful in reaching women. This gives micro-finance institutions an extraordinary opportunity to act intentionally to empower poor women and to minimize the potentially negative impacts some women experiences. Thus studies related to women empowerment and SHGs, also shows that well nurtured SHGs as a model of micro finance in India resulted in increased participation of women in various household and other decision making process leading to the empowerment in different states.

Table 2a analyse various indicators of women empowerment in different states of India. Using NFHS 3 data on various variables of indicators of women empowerment such as participation of women in decision making, employment status, their excess to money and credit, attitude towards wife beating and education, ranking of states have been calculated and a consolidated ranking of women empowerment for the states has been derived.

In column 2 of the table 2 (b) total ranking has been calculated based on the ranks on the variables measuring evidence of empowerment such as women's participation in decision making, employment and cash employment, Women's access to money and credit, women's attitude towards wife beating and women education. On the basis of these total ranking state wise women empowerment ranking has been prepared in column 3. Column 4 represents average rural Below Poverty Line (BPL) population per SHG in different states and in column 5 ranking of different states have been done on the basis of average number of rural BPL population per SHGs bank linked.

Table 2 (c) shows the grouping of states according to the rank in the number of SHGs bank linked. All four Southern states, Maharashtra, Goa and some of the northern states like Tripura, Mizoram, and Himachal Pradesh come within the 10 ranks whereas states like Bihar, Madhya Pradesh, Uttar Pradesh, Jharkhand, Uttarakhand fall in the lower ranks of $20-30$. The grouping of the states on the basis of women empowerment ranking (table 2(d)) shows that most of the states which are falling under the group of first 10 ranks in terms of the number of SHGs bank linked come under the same 1 - 10 ranking in women empowerment. States like Uttar Pradesh, Madhya Pradesh, Bihar, Uttarakhand, Chattisgharh, Jammu Kashmir etc show a poor performance in women empowerment as well as number of SHGs bank linked.

Table2a. State wise Ranking of Different Indicators of Women Empowerment

\begin{tabular}{|c|c|c|c|c|c|c|c|c|c|c|c|c|c|c|c|}
\hline \multirow[t]{2}{*}{ States } & \multicolumn{3}{|c|}{$\begin{array}{c}\text { Women } \\
\text { participation in } \\
\text { decision } \\
\text { making }\end{array}$} & \multicolumn{3}{|c|}{$\begin{array}{l}\text { Employment and } \\
\text { Cash Employment }\end{array}$} & \multicolumn{6}{|c|}{$\begin{array}{c}\text { Women's access to money and } \\
\text { credit }\end{array}$} & \multirow{2}{*}{$\begin{array}{c}\text { Attitude } \\
\text { towards } \\
\text { wife } \\
\text { beating } \\
\text { (RB) }\end{array}$} & \multirow{2}{*}{$\begin{array}{l}\text { Rankin } \\
\text { g in } \\
\text { Women } \\
\text { Educati } \\
\text { on (RL) }\end{array}$} & \multirow{2}{*}{$\begin{array}{c}\text { Tota } \\
1 \\
\text { Ran } \\
\text { king }\end{array}$} \\
\hline & $\mathbf{R D}_{1}$ & $\mathbf{R D}_{\mathbf{2}}$ & $\begin{array}{c}\text { Total } \\
\text { RD }\end{array}$ & $\mathbf{R E}_{1}$ & $\mathbf{R E}_{2}$ & $\begin{array}{l}\text { Total } \\
\text { RE }\end{array}$ & $\mathbf{R C}_{\mathbf{1}}$ & $\mathbf{R C}_{2}$ & $\mathbf{R C}_{3}$ & $\mathbf{R C}_{4}$ & $\mathbf{R C}_{5}$ & $\begin{array}{c}\text { Tot } \\
\text { al } \\
\text { RC }\end{array}$ & & & \\
\hline $\begin{array}{l}\text { Andhra } \\
\text { Pradesh }\end{array}$ & 16 & 23 & 39 & 7 & 5 & 12 & 8 & 13 & 5 & 1 & 14 & 41 & 26 & 26 & 144 \\
\hline $\begin{array}{l}\text { Arunachal } \\
\text { Pradesh }\end{array}$ & 7 & 3 & 10 & 1 & 27 & 28 & 12 & 11 & 16 & 9 & 11 & 59 & 25 & 23 & 145 \\
\hline Assam & 5 & 12 & 17 & 28 & 4 & 32 & 25 & 22 & 9 & 18 & 18 & 92 & 6 & 15 & 162 \\
\hline
\end{tabular}


Dr. Ravindra K \& Dr. Abhay Kumar Tiwari

\begin{tabular}{|c|c|c|c|c|c|c|c|c|c|c|c|c|c|c|c|}
\hline Bihar & 24 & 28 & 52 & 19 & 20 & 39 & 4 & 25 & 20 & 23 & 27 & 99 & 17 & 30 & 237 \\
\hline Chhattisgarh & 27 & 18 & 45 & 2 & 25 & 27 & 21 & 26 & 18 & 19 & 30 & 114 & 3 & 20 & 209 \\
\hline Delhi & 8 & 9 & 17 & 30 & 1 & 31 & 10 & 2 & 19 & 21 & 16 & 68 & 2 & 8 & 126 \\
\hline Goa & 11 & 6 & 17 & 21 & 7 & 28 & 6 & 1 & 6 & 10 & 3 & 26 & 4 & 5 & 80 \\
\hline Gujarat & 20 & 14 & 34 & 8 & 17 & 25 & 5 & 10 & 8 & 15 & 8 & 46 & 18 & 12 & 135 \\
\hline Haryana & 15 & 15 & 30 & 27 & 19 & 46 & 19 & 21 & 14 & 27 & 10 & 91 & 7 & 14 & 188 \\
\hline $\begin{array}{c}\text { Himachal } \\
\text { Pradesh }\end{array}$ & 17 & 17 & 34 & 24 & 30 & 54 & 24 & 4 & 24 & 12 & 2 & 66 & 1 & 2 & 157 \\
\hline India & 19 & 21 & 40 & 15 & 15 & 30 & 9 & 16 & 13 & 7 & 20 & 65 & 16 & 19 & 170 \\
\hline $\begin{array}{c}\text { Jammu \& } \\
\text { Kashmir }\end{array}$ & 28 & 30 & 58 & 17 & 28 & 45 & 7 & 6 & 28 & 30 & 6 & 77 & 21 & 16 & 217 \\
\hline Jharkhand & 13 & 20 & 33 & 4 & 23 & 27 & 2 & 18 & 21 & 14 & 17 & 72 & 10 & 29 & 171 \\
\hline Karnataka & 22 & 26 & 48 & 12 & 12 & 24 & 1 & 5 & 7 & 3 & 23 & 39 & 23 & 18 & 152 \\
\hline Kerala & 10 & 10 & 20 & 26 & 2 & 28 & 29 & 3 & 1 & 4 & 19 & 56 & 24 & 1 & 129 \\
\hline $\begin{array}{l}\text { Madhya } \\
\text { Pradesh }\end{array}$ & 26 & 27 & 53 & 6 & 18 & 24 & 15 & 24 & 17 & 22 & 25 & 103 & 13 & 24 & 217 \\
\hline Maharashtra & 12 & 13 & 25 & 9 & 13 & 22 & 11 & 8 & 15 & 13 & 12 & 59 & 11 & 6 & 123 \\
\hline Manipur & 4 & 4 & 8 & 3 & 9 & 12 & 23 & 28 & 4 & 6 & 5 & 66 & 30 & 4 & 120 \\
\hline Meghalaya & 1 & 8 & 9 & 16 & 21 & 37 & 20 & 14 & 23 & 17 & 24 & 98 & 15 & 28 & 187 \\
\hline Mizoram & 3 & 2 & 5 & 14 & 16 & 30 & 30 & 27 & 30 & 26 & 1 & 114 & 29 & 3 & 181 \\
\hline Nagaland & 2 & 1 & 3 & 11 & 26 & 37 & 16 & 30 & 22 & 20 & 26 & 114 & 28 & 17 & 199 \\
\hline Orissa & 14 & 16 & 30 & 18 & 11 & 29 & 17 & 23 & 3 & 5 & 29 & 77 & 20 & 22 & 178 \\
\hline Punjab & 18 & 11 & 29 & 29 & 8 & 37 & 27 & 17 & 11 & 24 & 13 & 92 & 12 & 13 & 183 \\
\hline Rajasthan & 30 & 29 & 59 & 5 & 22 & 27 & 22 & 29 & 29 & 28 & 22 & 130 & 19 & 27 & 262 \\
\hline Sikkim & 6 & 5 & 11 & 22 & 14 & 36 & 14 & 7 & 25 & 25 & 7 & 78 & 27 & 10 & 162 \\
\hline Tamil Nadu & 9 & 7 & 16 & 10 & 3 & 13 & 28 & 15 & 2 & 2 & 4 & 51 & 22 & 7 & 109 \\
\hline Tripura & 25 & 19 & 44 & 25 & 10 & 35 & 26 & 12 & 12 & 11 & 15 & 76 & 14 & 9 & 178 \\
\hline $\begin{array}{c}\text { Uttar } \\
\text { Pradesh }\end{array}$ & 23 & 22 & 45 & 20 & 24 & 44 & 3 & 20 & 26 & 29 & 28 & 106 & 8 & 21 & 224 \\
\hline \begin{tabular}{|c|} 
UttaraKhan \\
$\mathrm{d}$
\end{tabular} & 21 & 24 & 45 & 13 & 29 & 42 & 18 & 9 & 27 & 16 & 9 & 79 & 9 & 11 & 186 \\
\hline
\end{tabular}

Source: $N F H S-3$

\section{Criteria of Ranking:}

1) $\mathrm{RD}_{1}$ - Percentage of currently married women who participate in four decisions (1.Own health care, 2. Making major household purchases, 3. Making purchases of daily household needs, 4. Visit her family or relatives) with the lowest rank going to states where this percentage is more.

$\mathrm{RD}_{2}$ - Percentage of women currently married who participated in none of the above four decisions with the lowest rank going to the state where this percentage is less.

$\mathrm{RD}$ - Sum of $\mathrm{RD}_{1}$ and $\mathrm{RD}_{2}$

2) RE1 - Percentage of currently married women who are employed in the past 12 months with the lowest rank going to states where this percentage is more.

RE2 - Percentage of currently married women who are earning cash among those who are employed in the past 12 months with the lowest rank going to states where this percentage is more.

RE- Sum of the rankings of different parameters of currently married women who are employed.

3) RC1-Percentage of women who have money that they can decide how to use with the lowest rank going to states where this percentage is more

RC2 - Percentage of women who have a bank or saving accounts that they themselves use with the lowest rank going to states where this percentage is more

RC3 - Percentage of women who are aware of micro credit programme with the lowest rank going to states where this percentage is more

RC4- Percentage of women who have taken a loan from micro credit programme with the lowest rank going to states where this percentage is more

RC5 - Percentage of Women allowed to go to three specified places alone (To the market, to the health facility, and to places outside the village/community with the lowest rank going to states where this percentage is more 
Relationship between Poverty, Women Empowerment and SHGs: A Study of Indian States

RC - Sum of the rankings of different parameters of women's participation in access to money and credit.

4) RB- Percentage of women who justify husband in wife beating for at least one of the specified reasons such as 1 . If she goes out without telling him, 2. She neglects house or children, 3. She argues with him, 4. She refuses to have sexual intercourse with him, 5. She does not cook properly, 6. He suspects she is unfaithful, 7. She shows disrespect for her in-laws.

5) RL- Percentage of literate women with lowest ranking going to states where this percentage is more.

6) Total Ranking of empowerment is calculated on the basis of sum of the ranks on the variables measuring evidence of empowerment (RD, RE, RC, RB and RL)

Table 2(b). Ranking of States with respect to women empowerment and SHGs bank linked

\begin{tabular}{|c|c|c|c|c|}
\hline State & $\begin{array}{c}\text { Total ranking of } \\
\text { different women } \\
\text { empowerment indicators }\end{array}$ & $\begin{array}{l}\text { Women } \\
\text { empowerment } \\
\text { ranking }\end{array}$ & $\begin{array}{l}\text { Number of Rural } \\
\text { BPL population } \\
\text { per SHG }\end{array}$ & $\begin{array}{c}\text { Ranking of states in } \\
\text { terms of SHGs } \\
\text { bank linked }\end{array}$ \\
\hline 1 & 2 & 3 & 4 & 5 \\
\hline Andhra Pradesh & 144 & 8 & 3 & 3 \\
\hline Arunachal Pradesh & 145 & 9 & 29 & 15 \\
\hline Assam & 162 & 12 & 23 & 11 \\
\hline Bihar & 237 & 29 & 202 & 30 \\
\hline Chhattisgarh & 209 & 25 & 48 & 22 \\
\hline Delhi & 126 & 5 & 1 & 1 \\
\hline Goa & 80 & 1 & 2 & 2 \\
\hline Gujarat & 135 & 7 & 44 & 21 \\
\hline Haryana & 188 & 23 & 44 & 20 \\
\hline Himachal Pradesh & 157 & 11 & 10 & 7 \\
\hline India & 170 & 14 & 94 & 28 \\
\hline Jammu Kashmir & 217 & 26 & 180 & 29 \\
\hline Jharkhand & 171 & 15 & 9 & 6 \\
\hline Karnataka & 152 & 10 & 7 & 4 \\
\hline Kerala & 129 & 6 & 82 & 26 \\
\hline Madhya Pradesh & 217 & 27 & 19 & 9 \\
\hline Maharashtra & 123 & 4 & 30 & 17 \\
\hline Manipur & 120 & 3 & 34 & 18 \\
\hline Meghalaya & 187 & 22 & 18 & 8 \\
\hline Mizoram & 181 & 18 & 49 & 24 \\
\hline Nagaland & 199 & 24 & 29 & 16 \\
\hline Orissa & 178 & 16 & 44 & 21 \\
\hline Punjab & 183 & 19 & 25 & 13 \\
\hline Rajasthan & 262 & 30 & 35 & 19 \\
\hline Sikkim & 162 & 13 & 49 & 23 \\
\hline Tamil Nadu & 109 & 2 & 8 & 5 \\
\hline Tripura & 178 & 17 & 21 & 10 \\
\hline Uttar Pradesh & 224 & 28 & 91 & 27 \\
\hline UttaraKhand & 186 & 21 & 62 & 25 \\
\hline West Bengal & 184 & 20 & 24 & 12 \\
\hline
\end{tabular}

Table 2(c). Grouping according to the Ranking of SHG

\begin{tabular}{|c|c|c|c|c|c|}
\hline State & SHG Rank & State & SHG Rank & State & SHG Rank \\
\hline Delhi & 1 & Assam & 11 & Gujarat & 21 \\
\hline Goa & 2 & West Bengal & 12 & Chhattisgarh & 22 \\
\hline Andhra Pradesh & 3 & Punjab & 13 & Sikkim & 23 \\
\hline Kerala & 4 & All India & 14 & Nagaland & 24 \\
\hline Tamil Nadu & 5 & Arunachal Pradesh & 15 & UttaraKhand & 25 \\
\hline Karnataka & 6 & Orissa & 16 & Madhya Pradesh & 26 \\
\hline Himachal Pradesh & 7 & Manipur & 17 & Uttar Pradesh & 27 \\
\hline Mizoram & 8 & Meghalaya & 18 & Jammu \& Kashmir & 28 \\
\hline Maharashtra & 9 & Rajasthan & 19 & Jharkhand & 29 \\
\hline Tripura & 10 & Haryana & 20 & Bihar & 30 \\
\hline
\end{tabular}


Dr. Ravindra K \& Dr. Abhay Kumar Tiwari

Table 2(d). Grouping according to the ranking of women empowerment

\begin{tabular}{|c|c|c|c|c|c|}
\hline State & $\begin{array}{c}\text { Women } \\
\text { empowerment } \\
\text { Rank }\end{array}$ & State & $\begin{array}{c}\text { Women } \\
\text { empowerment } \\
\text { Rank }\end{array}$ & State & $\begin{array}{c}\text { Women } \\
\text { empowerment } \\
\text { Rank }\end{array}$ \\
\hline Goa & 1 & Himachal & 11 & Uttarakhand & 21 \\
\hline Tamil & 2 & Assam & 12 & Meghalaya & 22 \\
\hline Manipur & 3 & Sikkim & 13 & Haryana & 23 \\
\hline Maharashtra & 4 & India & 14 & Nagaland & 24 \\
\hline Delhi & 5 & Jharkhand & 15 & Chhattisgarh & 25 \\
\hline Kerala & 6 & Orissa & 16 & Jammu \& Kashmir & 26 \\
\hline Gujarat & 7 & Tripura & 17 & Madhya Pradesh & 27 \\
\hline Andhra Pradesh & 8 & Mizoram & 18 & Uttar Pradesh & 28 \\
\hline Arunachal Pradesh & 9 & Punjab & 19 & Bihar & 29 \\
\hline Karnataka & 10 & West Bengal & 20 & Rajasthan & 30 \\
\hline
\end{tabular}

\section{Poverty, Women EMPOWERMENT AND SHGS}

Table 3 represents the ranking of the major states in terms of Poverty, performance in women empowerment and number of SHGs bank linked. An analysis of the table reveals that almost all Southern states like Andhra Pradesh, Karnataka, Kerala shows a better performance in women empowerment, poverty alleviation and in the number of SHG. Tamil Nadu stands in the same position accept in terms of poverty. In terms of Poverty its shares eighth rank. It is also evident from the analysis that states like Uttar Pradesh, Bihar, Madhya Pradesh fall under the lower rank of poverty, women empowerment and the number of SHGs bank linked. It should also be noted that these states consists of about 30 per cent of the total population and about 45 percent of the total BPL population of India.

In table 4, a rank correlation has been calculated for the major states with respect of poverty \& SHGs, and women empowerment \& SHGs. It reveals that there is a high rank correlation between women empowerment and SHGs (0.71) and between poverty and SHGs (0.60).

Table3. Ranking of major states* according to poverty, women empowerment and SHG

\begin{tabular}{|c|c|c|c|c|c|c|c|c|}
\hline \multicolumn{3}{|c|}{ Poverty Ranking } & \multicolumn{3}{|c|}{$\begin{array}{c}\text { Women Empowerment } \\
\text { Ranking } \\
\end{array}$} & \multicolumn{3}{|c|}{ SHG Ranking } \\
\hline State & $\begin{array}{c}\% \text { of Rural } \\
\text { BPL } \\
\text { population }\end{array}$ & $\begin{array}{c}\text { Rank } \\
\text { ing }\end{array}$ & State & $\begin{array}{c}\text { Total } \\
\text { ranki } \\
\text { ng }\end{array}$ & $\begin{array}{l}\text { Ran } \\
\text { king }\end{array}$ & State & \begin{tabular}{|c|} 
No of Rural \\
BPL \\
Population per \\
SHG
\end{tabular} & $\begin{array}{l}\text { Ran } \\
\text { king }\end{array}$ \\
\hline Punjab & 5.9 & 1 & Tamil Nadu & 109 & 1 & Andhra Pradesh & 3 & 1 \\
\hline Andhra Pradesh & 7.5 & 2 & Maharashtra & 123 & 2 & Kerala & 7 & 2 \\
\hline Haryana & 9.2 & 3 & Kerala & 129 & 3 & Tamil Nadu & 8 & 3 \\
\hline Kerala & 9.6 & 4 & Gujarat & 135 & 4 & Karnataka & 9 & 4 \\
\hline Karnataka & 12 & 5 & Andhra Pradesh & 144 & 5 & Maharashtra & 19 & 5 \\
\hline Gujarat & 13.9 & 6 & Karnataka & 152 & 6 & Assam & 23 & 6 \\
\hline Rajasthan & 14.3 & 7 & Assam & 162 & 7 & West Bengal & 24 & 7 \\
\hline Tamil Nadu & 16.9 & 8 & Jharkhand & 171 & 8 & Punjab & 25 & 8 \\
\hline Assam & 17 & 9 & Orissa & 178 & 9 & Orissa & 29 & 9 \\
\hline Maharashtra & 22.2 & 10 & Punjab & 183 & 10 & Rajasthan & 35 & 10 \\
\hline West Bengal & 24.2 & 11 & West Bengal & 184 & 11 & Haryana & 44 & 11 \\
\hline Uttar Pradesh & 25.3 & 12 & Haryana & 188 & 12 & Gujarat & 44 & 12 \\
\hline Madhya Pradesh & 29.8 & 13 & Chhattisgarh & 209 & 13 & Chhattisgarh & 48 & 13 \\
\hline Chhattisgarh & 31.2 & 14 & Madhya Pradesh & 217 & 14 & Madhya Pradesh & 82 & 14 \\
\hline Bihar & 32.9 & 15 & Uttar Pradesh & 224 & 15 & Uttar Pradesh & 91 & 15 \\
\hline Orissa & 39.8 & 16 & Bihar & 237 & 16 & Jharkhand & 180 & 16 \\
\hline Jharkhand & 40.2 & 17 & Rajasthan & 262 & 17 & Bihar & 202 & 17 \\
\hline
\end{tabular}

* States having population above one percent of the total population. 
Relationship between Poverty, Women Empowerment and SHGs: A Study of Indian States

Table4. Rank Correlation between Poverty \& SHGs and Women Empowerment \& SHGs

\begin{tabular}{|c|c|c|c|c|c|c|c|c|}
\hline \multicolumn{3}{|c|}{$\begin{array}{c}\text { Rank Correlation between } \\
\text { Poverty \& SHGs }\end{array}$} \\
\hline States & $\begin{array}{c}\text { Poverty } \\
\text { Ranking* }\end{array}$ & $\begin{array}{c}\text { SHG } \\
\text { Ranking* }\end{array}$ & $\begin{array}{c}\text { Difference in } \\
\text { Ranking (D) }\end{array}$ & $\mathbf{D}^{\mathbf{2}}$ & $\begin{array}{c}\text { Women } \\
\text { Empowerment } \\
\text { Ranking* }\end{array}$ & $\begin{array}{c}\text { SHG } \\
\text { Ranking } \\
*\end{array}$ & $\begin{array}{c}\text { Difference } \\
\text { in Ranking } \\
\text { (D) }\end{array}$ & D $^{\mathbf{2}}$ \\
\hline Andhra Pradesh & 3 & 1 & 2 & 4 & 5 & 1 & 4 & 16 \\
\hline Assam & 8 & 6 & 2 & 4 & 7 & 6 & 1 & 1 \\
\hline Bihar & 15 & 17 & -2 & 4 & 16 & 17 & -1 & 1 \\
\hline Chhattisgarh & 14 & 13 & 1 & 1 & 13 & 13 & 0 & 0 \\
\hline Gujarat & 6 & 12 & -6 & 36 & 4 & 12 & -8 & 64 \\
\hline Haryana & 2 & 11 & -9 & 81 & 12 & 11 & 1 & 1 \\
\hline Jharkhand & 17 & 16 & 1 & 1 & 8 & 16 & -8 & 64 \\
\hline Karnataka & 5 & 4 & 1 & 1 & 6 & 4 & 2 & 4 \\
\hline Kerala & 4 & 2 & 2 & 4 & 3 & 2 & 1 & 1 \\
\hline Madhya Pradesh & 13 & 14 & -1 & 1 & 14 & 14 & 0 & 0 \\
\hline Maharashtra & 10 & 5 & 5 & 25 & 2 & 5 & -3 & 9 \\
\hline Orissa & 16 & 9 & 7 & 49 & 9 & 9 & 0 & 0 \\
\hline Punjab & 1 & 8 & -7 & 49 & 10 & 8 & 2 & 4 \\
\hline Rajasthan & 7 & 10 & -3 & 9 & 17 & 10 & 7 & 49 \\
\hline Tamil Nadu & 8 & 3 & 5 & 25 & 1 & 3 & -2 & 4 \\
\hline Uttar Pradesh & 12 & 16 & -4 & 16 & 15 & 15 & 0 & 0 \\
\hline West Bengal & 11 & 7 & 4 & 16 & 11 & 7 & 4 & 16 \\
\hline Rank Correlation & coefficient between poverty and SHGs & 0.60 & Rank Correlation coefficient between & women empowerment and SHGs & 0.71 \\
\hline
\end{tabular}

*From Table No. 3

Note: Rank Correlation Coefficient $=1-\frac{6 \sum_{i=1}^{17} D i}{n^{3}-n}$

Where $n=$ Number of states $(n=17)$

$D_{i}=$ Difference in the ranks of the $i^{\text {th }}$ state

$(i=1,2 \ldots .17)$

\section{Conclusion}

The study shows that there is a relationship between poverty, women empowerment and SHGs. It is evident from the analysis that the growth of SHGs is slow in some of the major poverty ridden and dense populated northern states like Bihar, Uttar Pradesh, Madhya Pradesh etc. In terms of women empowerment also these states ranks below than other states. However, the southern states such as Andhra Pradesh, Karnataka, Kerala and Tamil Nadu where the SHG movement has become very successful, the intensity of poverty is less and they are doing better in terms of women empowerment. The World Bank's World Development Report 2000-2001identifies three priority areas for efforts to address poverty, promoting economic opportunity, facilitating empowerment and enhancing security. SHGs may be viewed as a better option to break the vicious circle of poverty and promote women empowerment since it addresses these three priority areas. The relationship between poverty, women empowerment and SHGs existed in the states of India supports this argument.

\section{REFERENCES}

Cheston, Susy and Lisa Kuhn (2002). Empowering Women through Microfinance, Unpublished Background Paper for the Micro-credit Summit 15, New York, 10-13 November (www.microcreditsummit.org).

Devaprakash (2005). Balancing Quality and Quantity in SHGs in India - IBA Bulletin 25 - August 2005.

Manimekalai, M. \&Rajeshwari, G., (2001).Nature and Performance Of Informal Self Help Groups - A Case From Tamil Nadu, IndianJournal Of Agricultural Economics, Vol. 56 (3), July-Sept, 2001.

MundleSubito (2010). Development is the Key - Times of India April 29, 2010 
NABARD (2009). Progress under Microfinance - as on 31 March 2009.

Narasiah, M.L. (2004).Women and Microcredit, Sonali Publications, New Delhi.

National Familty Health Survey -3 (2005-06). India data and reports International Institute for Population Sciences.

Pankaj Kumar and Ramesh Golait (2009). Bank Penetration and SHG-Bank Linkage Programme: A CritiqueReserve Bank of India Occasional Papers Vol. 29, No.3, 2009).

Puhazhehdhi, V (1999).Evaluation Study of SHG's: Important Findings of Evaluation Study in Tamil Nadu, Paper Presented in a Workshop, Dated 26-27 August, 1999, BIRD, Lucknow.

Puhazhendhi, V. \&Satyasai, KJ.S. (2001).Economic And Social Empowerment of Rural Poor through SHG's, Indian Journal OfAgricultural Economics, Vol. 56 (3), July-Sept., 2001.

Sa-Dhan (2003).Quality parameters of self-help groups: a discussion paper - discussion paper series 2

SrinivasanGirija (2000). Financial To Social Capital: Role of Banks, In Basu K. And Jindal K. (Ed), Microfiance, Emerging Challenges, TataMcgraw-Hill, New Delhi, 2000.

Srinivasan, G. \&Rao, D.S.K., (1996).Financing Of SHG's By Banks - Some Issues, Working Paper, 8, BIRD, Lucknow, 1996.

\section{AUTHORS' BIOGRAPHY}

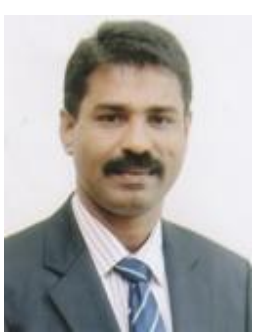

Dr. Rvindra K., M.A (Economics) Ph.D. (Mangalore University), MBA, is working as a faculty member in the Faculty of Business and Management Studies at Gulf College, Sultanate of Oman. He also served as a faculty member in IBS Dehradun as well as AJ Institute of Management Studies in Mangalore. He has about 22 years of teaching and research experience. He has published about 14 Research papers in various journals along with an edited book and also presented papers in various national seminars and conferences.

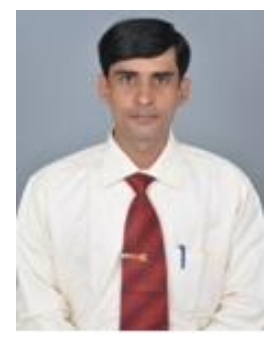

Dr. Abhay Kumar Tiwari, M. Sc. (Statistics), MBA, Ph. D. (BHU), is working as a Faculty Member \& Coordinator, Research at IBS, ICFAI University Dehradun. He has more thirteen years of teaching \& research experience. His teaching area is Research Methodology, Quantitative Methods etc. and research area is Applied Statistics. He has to his credit record of around $\mathbf{5 5}$ published research papers in reputed International \& Indian Journals and he has edited two books. He has also presented around $\mathbf{1 5}$ research papers at various National and International Conferences and supervised 4Ph. D Theses. He has successfully organized various National Conferences \& Workshops and served as resource person for various Workshops/FDPs. 